\title{
Composition and Yield of Colostrum and Milk from Murrah and "Murrah x Carabao" Crosses in the Philippines
}

\author{
O. L. Bondoc ${ }^{\mathrm{a}, *}$, T. Almendral-Saludes ${ }^{\mathrm{b}}$, A. G. Tandang ${ }^{\mathrm{b}}$, A. R. Bustos ${ }^{\mathrm{c}}$, A. R. Ramos ${ }^{\mathrm{a}}$, \& A. O. Ebron ${ }^{\mathrm{a}}$ \\ anstitute of Animal Science, College of Agriculture and Food Science, University of the Philippines Los Baños, \\ College, Laguna 4031, Philippines \\ bPhilippine Carabao Center at UP Los Baños, Department of Agriculture, \\ College, Laguna 4031, Philippines \\ 'Institute of Human Nutrition and Food, College of Human Ecology, University of the Philippines Los Baños, College, \\ Laguna 4031, Philippines \\ "Corresponding author: olbondoc@up.edu.ph \\ (Received 15-10-2020; Revised 31-01-2021; Accepted 09-02-2021)
}

\begin{abstract}
This study compared the composition, yield, and freezing point of buffalo colostrum and milk collected on the $30^{\text {th }}, 60^{\text {th }}$, and $90^{\text {th }}$ day of lactation from purebred Murrah and its crosses with the Philippine Carabao. A total of 133 milk samples were collected from 36 buffaloes (20 purebred Murrah and 16 "Murrah x Carabao" crosses) and evaluated for fat, protein, and lactose content, solids non-fat $(\mathrm{SNF})$, total solids, and freezing point. Colostrum contained significantly $(\mathrm{p}<0.05)$ more protein, $S N F$, total solids, and higher freezing point, but less moisture and lactose, and were produced in lower amounts than milk obtained on different days of lactation. Fat percentage was not significantly different ( $p>0.05$ ) between colostrum and milk. Colostrum from Murrah buffaloes had more protein but less fat and colostrum yield than "Murrah x Carabao" crosses. Among crossbred buffaloes, the F2 "75\% Murrah - 25\% Carabao" crosses produced more colostrum than F1 "50\% Murrah - 50\% Carabao" (p<0.05). Older buffaloes also produced more colostrum. Milk parameters were similar for Murrah and "Murrah $x$ Carabao" crosses, except for test-day milk yield, which was significantly higher in "Murrah x Carabao" crosses. The F1 crossbred buffaloes had milk containing more lactose and SNF, but lower freezing point than milk from F2 crossbred buffaloes. Buffaloes, already with more lactations, had higher test-day milk yield but with lower fat and total solids. High monthly temperature reduced test-day milk yield. In conclusion, breed differences, age at calving, number of lactations, and high monthly temperature may have caused changes in the composition and yield of buffalo colostrum and milk.
\end{abstract}

Keywords: colostrum; milk components; Murrah buffalo; Philippine carabao

\section{INTRODUCTION}

The water buffalo inventory in the Philippines, mostly of the swamp-type called the carabao, is about 2.9 million heads. In 2015, the dairy buffalo population in the Philippines was 17,802 heads. A total of 7.121 million liters (LME) of milk were produced from 4,983 buffaloes in the milking line (Philippine Statistics Authority, 2016). Total milk produced from buffaloes of various breeds was $38.49 \%$ by individual smallholder producers (who consume and sell locally what they produce), $30.17 \%$ by cooperatives (who deliver their milk to a collection point for transport to a processing plant), $24.80 \%$ by institutional farms (which supply school and rural community feeding programs), and $7.11 \%$ by commercial farms (which supply processors).

Milk production from carabaos is very low at about $2.8 \mathrm{~kg}$ /day/lactation, while the small population of the river-type Murrah breed have an average milk production of $7.2 \mathrm{~kg} /$ day/lactation (Philippine Statistics Authority, 2016). In this regard, the Philippine Carabao
Center (PCC) leads the national carabao upgrading program, which aims to accelerate the herd build-up of dairy buffaloes. While continuous upgrading of the carabao is known to increase milk productivity, its effects on the composition and yield of colostrum and milk at different days of lactation have not been studied.

Similar studies were conducted to compare milk from purebred Murrah and crossbred buffaloes in China (Sun et al., 2014; Ren et al., 2015; Han et al., 2017; Zhou et al., 2018). The composition and nutrient data on colostrum in comparison to milk, however, are not commonly reported. In addition to the analysis of milk components, information on the freezing point of buffalo milk can also be studied as it is now widely used not only to indicate adulteration but also as a quality criterion for calculating the price of raw milk purchased and processed into dairy products (Pesce et al., 2016). Such important information can be used to promote buffalo colostrum and milk as a rich source of nutrients for adult men and women. They may also contribute to the development of local reference materials used by health 
and nutrition professionals engaged in nutrition education and medical nutrition therapy.

This study aimed to compare the composition and yield of colostrum and milk collected on the $30^{\text {th }}, 60^{\text {th }}$, and $90^{\text {th }}$ day of lactation from purebred Murrah and its crosses with the carabao in the institutional herd of the PCC located inside the University of the Philippines Los Baños (UPLB) campus, Laguna, Philippines. The effects of calving and previous lactation records and monthly weather parameters-temperature, relative humidity, and rainfall on various colostrum and milk parameters were likewise determined.

\section{MATERIALS AND METHODS}

\section{Animal Care}

This study was conducted in compliance with the requirements of the Institutional Animal Care and Use Committee of the University of the Philippines Los Baños, Laguna, Philippines with Assigned Protocol No. 2019-0034.

\section{Experimental Animals and Data}

A total of 133 milk samples were collected in the period between April 4, 2019 and July 27, 2020 from 36 buffaloes (i.e., 20 purebred Murrah and 16 "Murrah x Carabao" crosses) at the Philippine Carabao Center dairy buffalo farm in UPLB, Laguna, Philippines (Table 1). The crossbred buffaloes consisted of 3 F1 " $50 \%$ Murrah - 50\% Carabao", 2 F2 "75\% Murrah - 25\% Carabao", 9 F3 “87.5\% Murrah - 12.5\% Carabao", and 2 F4 “93.75\% Murrah - 6.25\% Carabao". Buffaloes were equally managed to fulfill all welfare requirements and were kept in individual parturition pens about 2 weeks before calving. Buffaloes were fed with forage, and commercial lactating feed concentrates. The nutritional content of the lactating feeds was analyzed at the Animal Nutrition Division, Institute of Animal Science, College of Agriculture and Food Science, UPLB, and found to contain $15.52 \%$ crude protein, $5.87 \%$ crude fat, $11.99 \%$ crude fiber, $7.90 \%$ moisture, $8.74 \%$ ash, $1.02 \%$ calcium, and $0.58 \%$ phosphorus using the Semi-micro Kjeldahl distillation, Soxhlet extraction, Weende method, oven drying, ashing at $600^{\circ} \mathrm{C}$, Titrimetric, and ColorimetricUV-Vis method, respectively.

Colostrum and milk samples (approximately 500 $\mathrm{mL}$ ) were collected by hand or milking machine on the $30^{\text {th }}, 60^{\text {th, }}$ and $90^{\text {th }}$ day of lactation, placed in plastic bottles, and immediately frozen at $-20^{\circ} \mathrm{C}$ until further analysis. The MilkoScan Mars (FOSS Analytical A/S, Hillerod, Denmark) using the Fourier-transform infrared spectroscopy (FTIR) technology was used to determine $\%$ fat, $\%$ protein, $\%$ lactose, $\%$ solids non-fat (SNF), $\%$ total solids, and freezing point $\left({ }^{\circ} \mathrm{C}\right)$. Other data were also collected, including colostrum yield, test-day milk yield, calving and previous lactation records (i.e., age at calving, parity, average calving interval, total milk yield, lactation length, and daily milk yield) and weather parameters (i.e., monthly average temperature and relative humidity, and total monthly rainfall) corresponding with each colostrum or milk sample.

\section{Statistical Analysis}

Pearson product-moment correlation coefficients among the proportion and yield of milk components (fat, protein, and lactose) and freezing point, and their relationships with calving and previous lactation records, and with weather parameters were initially determined separately for colostrum and milk samples using the CORR procedure (SAS, 2009). Calving and lactation records and weather parameters found to be consistently and significantly correlated with proportion and yield of milk components were included as covariates in the statistical models.

The general least squares procedures for unbalanced data (SAS, 2009) were used to examine the principal sources of variation affecting each colostrum $/ \mathrm{milk}$ component and freezing point. Statistical significance was set at $p<0.05$. The final statistical models were determined separately to compare colostrum and milk, analyze colostrum, and analyze milk.

Statistical model (1) used to compare colostrum and milk was: $\mathbf{y} \mathbf{1}_{i j k l}=\boldsymbol{\mu}+$ BType $_{i}+$ MType $_{j}+$ (BType $\mathbf{x}$ MType $)_{i j}+$ TDMY $_{k}+\mathbf{e}_{i j k l}$ where $\mathrm{y}_{\mathrm{ijkl}}$ is the proportion and yield of components and freezing point of all colostrum and milk samples, $\mu$ is the overall mean, BTypei is the fixed effect of the $i^{\text {th }}$ type of breed - purebred Murrah and "Murrah x Carabao" crosses, MType is the fixed effect for the $j^{\text {th }}$ type of milk - colostrum, milk collected on the $30^{\text {th }}, 60^{\text {th }}$ and $90^{\text {th }}$ day of lactation, (BType $\mathrm{x}$ MType $)_{i j}$ is the interaction effect between $i^{\text {th }}$ type of breed and $j^{\text {th }}$ type of milk, and TDMY ${ }_{k}$ is the $k^{\text {th }}$ covariate effect of colostrum or test-day milk yield $(\mathrm{kg})$, and $\mathrm{e}_{i j k l}$ is the error term assumed to be normally distributed with the variance of errors as constant across observations.

Table 1. Number and distribution of buffaloes and milk samples (by breed and milk type)

\begin{tabular}{|c|c|c|c|c|c|c|}
\hline \multirow{2}{*}{ Breed type } & \multicolumn{4}{|c|}{ Milk type } & \multirow{2}{*}{$\begin{array}{c}\text { No. of } \\
\text { samples }\end{array}$} & \multirow{2}{*}{$\begin{array}{c}\text { No. of } \\
\text { buffaloes }\end{array}$} \\
\hline & Colostrum & Milk 30-d & Milk 60-d & Milk 90-d & & \\
\hline Purebred Murrah & 18 & 19 & 18 & 15 & 70 & 20 \\
\hline “Murrah x Carabao” Crosses & 16 & 16 & 16 & 15 & 63 & 16 \\
\hline F1 50\% Murrah - 50\% Carabao & 3 & 3 & 3 & 3 & 12 & 3 \\
\hline F2 75\% Murrah - 25\% Carabao & 2 & 2 & 2 & 2 & 8 & 2 \\
\hline F3 87.5\% Murrah -12.5\% Carabao & 9 & 9 & 9 & 8 & 35 & 9 \\
\hline F4 93.75\% Murrah - 6.25\% Carabao & 2 & 2 & 2 & 2 & 8 & 2 \\
\hline Total & 34 & 35 & 34 & 30 & 133 & 36 \\
\hline
\end{tabular}


Statistical model (2) used to analyze colostrum components, and the freezing point was: $\mathbf{y} \mathbf{2}_{i j k l}=\boldsymbol{\mu}+$ $\mathbf{B T y p e}_{i}+\mathbf{C Y}_{j}+\mathrm{AC}_{k}+\mathbf{e}_{i j k l}$ where $\mathrm{y}_{\mathrm{ijkl}}$ is the proportion and yield of components and freezing point of colostrum samples, $\mu$ is the overall mean, BTypei is the fixed effect of the $i^{\text {th }}$ type of breed - purebred Murrah and "Murrah x Carabao" crosses, $\mathrm{CY}_{j}$ is the $j^{\text {th }}$ covariate effect of colostrum yield on the day of calving $(\mathrm{kg}), \mathrm{AC}_{k}$ is the $k^{\text {th }}$ covariate effect of age at calving (yr), and $\mathrm{e}_{i j k l}$ is the error term assumed to be normally distributed with the variance of errors as constant across observations.

Statistical model (3) used to analyze milk components. Freezing point was: $\mathbf{y}_{i j k l m n o}=\boldsymbol{\mu}+$ BType $_{i}+$ MTDate $_{j}+\mathrm{TDMY}_{k}+\mathbf{P}_{l}+\mathbf{T e m p}_{m}+\mathbf{R H}_{n}+\mathbf{e}_{i j k l m n o}$ where $\mathrm{y} 3_{\mathrm{ijklmno}}$ is the proportion and yield of components and freezing point of milk samples, $\mu$ is the overall mean, BTypei is the fixed effect of the $i^{\text {th }}$ type of breed - purebred Murrah and "Murrah x Carabao" crosses), MTD is the fixed effect of the $i^{\text {th }}$ milk test date $-30^{\text {th }}, 60^{\text {th }}$ and $90^{\text {th }}$ day of lactation, $\mathrm{TDMY}_{k}$ is the $k^{\text {th }}$ covariate effect of test-day milk yield $(\mathrm{kg}), \mathrm{P}_{l}$ is the $l^{\text {th }}$ covariate effect of parity number, Temp $\mathrm{p}_{m}$ is the $m^{\text {th }}$ covariate effect of the average monthly temperature $\left({ }^{\circ} \mathrm{C}\right), \mathrm{RH}_{n}$ is the $n^{\text {th }}$ covariate effect of the average monthly relative humidity $(\%)$, and $\mathrm{e}_{i j k l m n o}$ is the error term assumed to be normally distributed with the variance of errors as constant across observations.

Comparisons among "Murrah x Carabao" crosses were based on the statistical models (2) and (3) above, but replacing BType $_{i}$ with Breed $_{i}$ (i.e., $i^{\text {th }}$ breed, namely 100\% Murrah, F1 "50\% Murrah - 50\% Carabao", F2 "75\% Murrah - 25\% Carabao", F3 "87.5\% Murrah
- 12.5\% Carabao", and F4 "93.75\%Murrah - 6.25\% Carabao).

\section{RESULTS}

\section{Correlations Among Colostrum Parameters}

Percent fat in buffalo colostrum was positively correlated with fat yield $(\mathrm{r}=0.66)$. Percent protein was positively correlated with protein yield $(\mathrm{r}=0.65)$. However, percent lactose was not correlated with lactose yield (Table 2). Percent fat was negatively correlated with \% lactose $(\mathrm{r}=-0.54)$ but not correlated with \% protein and $\%$ lactose. Percent total solids was positively related to $\%$ protein $(\mathrm{r}=0.88)$, but negatively correlated to \% lactose $(r=-0.43)$. Percent total solids were not related to $\%$ fat.

Freezing point of colostrum was positively correlated with $\%$ moisture $(\mathrm{r}=0.47)$ and $\%$ fat $(\mathrm{r}=0.37)$, but negatively correlated with $\%$ protein $(r=-0.60), \%$ SNF $(\mathrm{r}=-0.69)$ and $\%$ total solids $(\mathrm{r}=-0.47)$. Freezing point was not correlated with \% lactose and lactose yield.

\section{Correlations among Milk Parameters}

Percent fat in buffalo milk was positively correlated with fat yield $(\mathrm{r}=0.80)$. Percent protein was positively correlated with protein yield $(r=0.83)$. Percent lactose was correlated with lactose yield $(\mathrm{r}=0.53)$, see Table 3. Percent fat was not correlated with \% protein and \% lactose. Percent protein was positively correlated with $\%$ lactose $(r=0.24)$. Percent total solids was positively

Table 2. Pearson correlation coefficients among buffalo colostrum composition, yield, and freezing point and their relationships with calving and previous lactation records and with monthly weather parameters

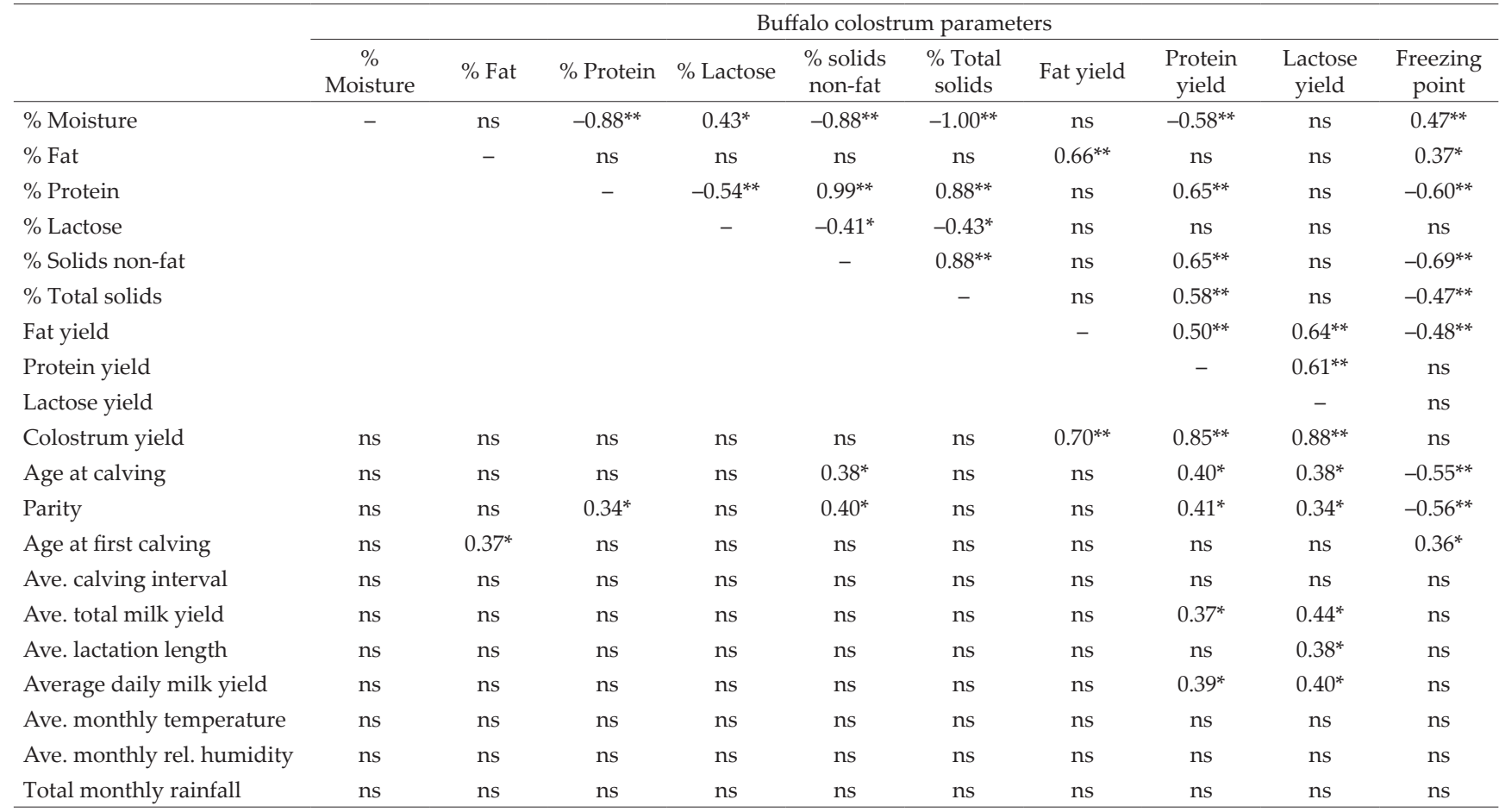

Note: $\mathrm{ns}=$ not significant $(\mathrm{p}>0.05) ;{ }^{*}=$ means $\mathrm{r}$ is significantly different from zero $(\mathrm{p}<0.05) ;{ }^{* *}=$ means $\mathrm{r}$ is significantly different from $z e r o(p<0.01)$. 
related to $\%$ fat $(\mathrm{r}=0.84), \%$ protein $(\mathrm{r}=0.52)$, and lactose $(\mathrm{r}=0.51)$.

Freezing point of buffalo milk was positively correlated with $\%$ moisture $(\mathrm{r}=0.27)$, but negatively correlated with $\%$ protein $(\mathrm{r}=-0.40), \%$ lactose $(\mathrm{r}=-0.83)$, $\%$ SNF $(r=-0.77)$, and $\%$ total solids $(r=-0.27)$. Freezing point was not correlated with $\%$ fat.

\section{Correlations of Colostrum and Milk Parameters with Calving and Previous Lactation Records and with Weather Parameters}

Colostrum yield in buffaloes was positively correlated with fat yield $(\mathrm{r}=0.70)$, protein yield $(\mathrm{r}=0.85)$, and lactose yield $(\mathrm{r}=0.88)$. Percent lactose and $\%$ total solids were not correlated with colostrum yield, calving, and the previous lactation records monthly temperature, monthly relative humidity, and monthly total rainfall.

Test-day milk yield was also positively correlated with fat yield $(\mathrm{r}=0.52)$, protein yield $(\mathrm{r}=0.70)$, and lactose yield $(r=0.82)$. Percent lactose, SNF, and \% total solids in buffalo milk were not correlated with test-day milk yield, calving, and previous lactation records. Fat yield, protein yield, and lactose yield were not correlated with monthly temperature, monthly relative humidity, and monthly total rainfall.

\section{Factors Affecting Colostrum and Milk Parameters}

In this study, percent fat is the most variable of the components of colostrum/milk with a coefficient variation $(\mathrm{CV})$ of $47.00 \%$, followed by percent protein $(\mathrm{CV}=$ $35.52 \%)$, percent lactose $(\mathrm{CV}=18.72 \%)$, and percent moisture $(\mathrm{CV}=4.08 \%)$. Among the major component yields, protein has the highest coefficient of variation, followed by fat and lactose (Table 4).

The type of breed had significant effects $(p<0.01)$ on most colostrum parameters except fat yield and lactose yield (Table 5). Colostrum yield had significant effects $(\mathrm{p}<0.05)$ on its fat, protein, and lactose yield. A higher colostrum yield is thus likely to produce more protein, fat, and lactose. The age of the buffalo at calving also had a significant effect $(\mathrm{p}<0.05)$ on freezing point and colostrum yield. This implies that older buffaloes are likely to produce more colostrum on the day of calving (i.e., additional $0.29 \mathrm{~kg}$ colostrum produced on the day of calving for each year increase in age at calving), but with a lower freezing point.

The type of breed also had significant effects $(p<0.01)$ on test-day milk yield (Table 6$)$. The proportion and yield of milk components were also affected by the test-day milk yield, age at calving, parity, average monthly temperature, and average monthly relative humidity. Higher test-day milk yield means more fat, protein, and lactose yields. Older buffaloes at calving produced milk with a higher percentage of fat and total solids. Buffaloes, already with more lactations, produced more milk (i.e., additional $0.57 \mathrm{~kg}$ milk yield per day for each unit increase in parity number), but with lower percentage fat and total solids. Higher average monthly temperature reduced the amount of milk produced (i.e., $0.69 \mathrm{~kg}$ decline in milk yield per day for every $1^{\circ} \mathrm{C}$ increase in monthly temperature), but with higher percentage lactose and SNF. Higher average monthly relative humidity reduced percentage protein, $\mathrm{SNF}$, and total solids in milk (i.e., $0.05 \%$ protein, $0.08 \%$

Table 3. Pearson correlation coefficients among buffalo milk composition, yield, and freezing point and their relationships with calving and previous lactation records and with monthly weather parameters

\begin{tabular}{|c|c|c|c|c|c|c|c|c|c|c|}
\hline & \multicolumn{10}{|c|}{ Buffalo milk parameters } \\
\hline & $\begin{array}{c}\% \\
\text { Moisture }\end{array}$ & $\%$ Fat & $\%$ Protein & $\%$ Lactose & $\begin{array}{c}\% \text { solids } \\
\text { non-fat }\end{array}$ & $\begin{array}{c}\text { \% Total } \\
\text { solids }\end{array}$ & Fat yield & $\begin{array}{c}\text { Protein } \\
\text { yield }\end{array}$ & $\begin{array}{c}\text { Lactose } \\
\text { yield }\end{array}$ & $\begin{array}{c}\text { Freezing } \\
\text { point }\end{array}$ \\
\hline \% Moisture & - & $-0.84^{* *}$ & $-0.52^{* *}$ & $-0.51^{* *}$ & $-0.62^{* *}$ & $-1.00^{* *}$ & $-0.73^{* *}$ & $-0.33^{* *}$ & $-0.32^{*}$ & $0.27^{* *}$ \\
\hline$\%$ Fat & & - & ns & ns & ns & $0.84^{* *}$ & $0.80^{* *}$ & ns & ns & ns \\
\hline$\%$ Protein & & & - & $0.24^{*}$ & $0.81^{* *}$ & $0.52^{* *}$ & ns & $0.83^{* *}$ & $0.26^{*}$ & $-0.40^{* *}$ \\
\hline$\%$ Lactose & & & & - & $0.76^{* *}$ & $0.51^{* *}$ & ns & ns & $0.53^{* *}$ & $-0.83^{* *}$ \\
\hline$\%$ Solids non-fat & & & & & - & $0.62^{* *}$ & ns & $0.58^{* *}$ & $0.50^{* *}$ & $-0.77^{* *}$ \\
\hline$\%$ Total solids & & & & & & - & $0.73^{* *}$ & $0.33^{* *}$ & $0.32^{*}$ & $-0.27^{* *}$ \\
\hline Fat yield & & & & & & & - & $0.33^{* *}$ & $0.54^{* *}$ & ns \\
\hline Protein yield & & & & & & & & - & $0.56^{* *}$ & ns \\
\hline Lactose yield & & & & & & & & & - & $-0.41^{* *}$ \\
\hline Test-day milk yield & ns & ns & $0.23^{*}$ & ns & ns & ns & $0.52^{* *}$ & $0.70^{* *}$ & $0.82^{* *}$ & ns \\
\hline Age at calving & ns & $0.24^{*}$ & ns & ns & ns & ns & ns & ns & ns & $0.24^{*}$ \\
\hline Parity & ns & ns & ns & ns & ns & ns & ns & ns & ns & $0.23^{*}$ \\
\hline Age at first calving & ns & ns & ns & ns & ns & ns & ns & ns & ns & ns \\
\hline Ave. calving interval & ns & ns & ns & ns & ns & ns & ns & ns & ns & ns \\
\hline Ave. total milk yield & ns & ns & ns & ns & ns & ns & ns & ns & ns & ns \\
\hline Ave. lactation length & ns & ns & ns & ns & ns & ns & ns & ns & ns & ns \\
\hline Average daily milk yield & ns & ns & ns & ns & ns & ns & ns & ns & ns & ns \\
\hline Ave. monthly temperature & ns & ns & ns & $0.24^{*}$ & ns & ns & ns & ns & ns & ns \\
\hline Ave. monthly rel. humidity & $0.22^{*}$ & ns & $-0.29^{* *}$ & ns & $-0.31^{* *}$ & $-0.22^{*}$ & ns & ns & ns & $0.22^{*}$ \\
\hline Total monthly rainfall & ns & ns & ns & ns & ns & ns & ns & ns & ns & ns \\
\hline
\end{tabular}

Note: $\mathrm{ns}=$ not significant $(\mathrm{p}>0.05) ;{ }^{*}=$ means $\mathrm{r}$ is significantly different from zero $(\mathrm{p}<0.05)$; ${ }^{* *}=$ means $\mathrm{r}$ is significantly different from zero $(\mathrm{p}<0.01)$. 
Table 4. Mean square F tests results for the effects of breed type, milk type, "Breed type x milk type" interaction, and covariate (testday milk yield) on different buffalo colostrum/ milk parameters

\begin{tabular}{lccccc}
\hline & Breed type & Milk type & $\begin{array}{c}\text { "Breed type } \text { milk type" } \\
\text { interaction }\end{array}$ & $\begin{array}{c}\text { Test-day milk } \\
\text { yield }\end{array}$ & CV (\%) \\
\hline \% Moisture & $\mathrm{ns}$ & $* *$ & $\mathrm{~ns}$ & $\mathrm{~ns}$ & 4.08 \\
\% Fat & $\mathrm{ns}$ & $\mathrm{ns}$ & $\mathrm{ns}$ & $\mathrm{ns}$ & 47.00 \\
\% Protein & $\mathrm{ns}$ & $* *$ & $\mathrm{~ns}$ & $\mathrm{~ns}$ & 35.52 \\
\% Lactose & $\mathrm{ns}$ & $* *$ & $\mathrm{~ns}$ & & 18.72 \\
$\%$ Solids non-fat & $\mathrm{ns}$ & $* *$ & $\mathrm{~ns}$ & $\mathrm{~ns}$ & 20.98 \\
\% Total solids & $\mathrm{ns}$ & $* *$ & $\mathrm{~ns}$ & $\mathrm{~ns}$ & 20.68 \\
Freezing point & $\mathrm{ns}$ & $*$ & $\mathrm{~ns}$ & $* *$ & $<0.00$ \\
Fat yield & $\mathrm{ns}$ & $\mathrm{ns}$ & $\mathrm{ns}$ & $* *$ & 46.85 \\
Protein yield & $\mathrm{ns}$ & $* *$ & $\mathrm{~ns}$ & $* *$ & 50.81 \\
Lactose yield & $\mathrm{ns}$ & $* *$ & $\mathrm{~ns}$ & - & 22.50 \\
Test-day milk yield & $* *$ & $*$ & & & 31.93 \\
\hline
\end{tabular}

Note: $\mathrm{CV}=$ coefficient of variation; ns $=$ not significant $(\mathrm{p}>0.05) ;{ }^{*}=$ means significant effect of independent variable $(\mathrm{p}<0.05) ;{ }^{* *}=$ means highly significant effect of independent variable $(\mathrm{p}<0.01)$.

Table 5. Mean square F test results for the effects of breed type and regression coefficients (zero-intercept model) for significant covariate effects of colostrum yield and age at calving on different buffalo colostrum parameters

\begin{tabular}{|c|c|c|c|c|}
\hline \multirow{2}{*}{ Colostrum parameters } & \multirow{2}{*}{ Breed type } & \multicolumn{2}{|c|}{ Covariates } & \multirow{2}{*}{$\mathrm{CV}(\%)$} \\
\hline & & Colostrum yield & Age at calving & \\
\hline \% Moisture & ** & ns & ns & 5.84 \\
\hline$\%$ Fat & $* *$ & ns & ns & 50.11 \\
\hline$\%$ Protein & $* *$ & ns & ns & 31.24 \\
\hline$\%$ Lactose & $* *$ & ns & ns & 26.44 \\
\hline$\%$ Solids non-fat & $* *$ & ns & ns & 23.38 \\
\hline$\%$ Total solids & $* *$ & ns & ns & 21.05 \\
\hline Freezing point & $* *$ & ns & ${ }^{*} \mathrm{~b}=-0.012$ & $<0.00$ \\
\hline Fat yield & ns & $* * b=0.038$ & ns & 53.16 \\
\hline Protein yield & $* *$ & ${ }^{*} \mathrm{~b}=0.162$ & ns & 36.76 \\
\hline Lactose yield & ns & ${ }^{* *} \mathrm{~b}=0.018$ & ns & 24.93 \\
\hline Colostrum yield & $* *$ & - & ${ }^{*} \mathrm{~b}=0.290$ & 43.27 \\
\hline
\end{tabular}

Note: $C V=$ coefficient of variation; $n s=$ not significant $(p>0.05) ;) ; b=$ regression coefficient; ${ }^{*}=$ means significant effect of independent variable $(p<0.05)$. ** = means highly significant effect of independent variable $(\mathrm{p}<0.01)$.

Table 6. Mean square F test results for the effects of breed type and milk test date and regression coefficients (zero-intercept model) for significant covariate effects of test-day milk yield, age at calving, parity, monthly temperature, and monthly relative humidity on milk collected on different buffalo milk parameters

\begin{tabular}{|c|c|c|c|c|c|c|c|c|}
\hline \multirow{2}{*}{$\begin{array}{c}\text { Milk } \\
\text { parameters }\end{array}$} & \multirow[b]{2}{*}{ Breed type } & \multirow{2}{*}{$\begin{array}{l}\text { Milk test } \\
\text { date }\end{array}$} & \multicolumn{5}{|c|}{ Covariates } & \multirow[b]{2}{*}{$\mathrm{CV}(\%)$} \\
\hline & & & $\begin{array}{l}\text { Test-day } \\
\text { milk yield }\end{array}$ & $\begin{array}{l}\text { Age at } \\
\text { calving }\end{array}$ & Parity & $\begin{array}{c}\text { Monthly } \\
\text { temperature }\end{array}$ & $\begin{array}{c}\text { Monthly rel. } \\
\text { humidity }\end{array}$ & \\
\hline$\%$ Moisture & ns & ns & ns & ${ }^{* *} \mathrm{~b}=-0.905$ & ${ }^{*} b=0.998$ & ns & ${ }^{*} b=0.143$ & 3.20 \\
\hline$\%$ Fat & ns & ns & ns & ${ }^{* *} \mathrm{~b}=0.776$ & ${ }^{*} \mathrm{~b}=-0.770$ & ns & ns & 43.99 \\
\hline$\%$ Protein & ns & ns & ${ }^{* *} b=0.145$ & ns & ns & ns & ${ }^{*} \mathrm{~b}=-0.054$ & 23.33 \\
\hline$\%$ Lactose & ns & ns & ns & ns & ns & ${ }^{*} b=0.259$ & ns & 16.82 \\
\hline$\%$ Solids non-fat & ns & ns & ${ }^{*} \mathrm{~b}=0.176$ & ns & ns & ${ }^{*} \mathrm{~b}=0.445$ & ${ }^{*} \mathrm{~b}=-0.077$ & 14.99 \\
\hline$\%$ Total solids & ns & ns & ns & $* * b=0.905$ & ${ }^{*} \mathrm{~b}=-0.998$ & ns & ${ }^{*} \mathrm{~b}=-0.143$ & 18.56 \\
\hline Freezing point & ns & ns & ns & ns & ns & ns & ns & $<0.00$ \\
\hline Fat yield & ns & ns & ${ }^{* *} b=0.048$ & $* * b=0.045$ & ${ }^{*} b=-0.047$ & ns & ns & 43.74 \\
\hline Protein yield & ns & ns & ${ }^{* *} \mathrm{~b}=0.055$ & ns & ns & ns & ${ }^{*} \mathrm{~b}=-0.005$ & 37.29 \\
\hline Lactose yield & ns & ns & ${ }^{*} \mathrm{~b}=0.046$ & ns & ns & ${ }^{*} \mathrm{~b}=0.021$ & ns & 18.99 \\
\hline $\begin{array}{l}\text { Test-day milk } \\
\text { yield }\end{array}$ & $* *$ & ns & - & ns & ${ }^{*} b=0.571$ & $* * b=-0.690$ & ns & 27.02 \\
\hline
\end{tabular}

Note: $C V=$ coefficient of variation; $n s=$ not significant $(p>0.05) ;)$; $=$ regression coefficient; ${ }^{*}=$ means significant effect of independent variable $(p<0.05)$. $* *=$ means highly significant effect of independent variable $(p<0.01)$. 
SNF, and $0.14 \%$ total solids decrease for every $1 \%$ increase in monthly relative humidity).

\section{DISCUSSION}

\section{Comparisons between Colostrum and Milk}

Colostrum had a significantly higher percentage of protein, SNF, and total solids, protein yield, and freezing point than milk obtained on the $30^{\text {th }}, 60^{\text {th }}$, and $90^{\text {th }}$ day of lactation. On the other hand, colostrum had lower \% moisture, \% lactose, lactose yield, and amount of colostrum produced than milk. Percent fat and fat yield were not significantly different between colostrum and milk (Table 7). Differences in the proportion and yield of milk components of milk obtained on the $30^{\text {th }}$, $60^{\text {th }}$, and $90^{\text {th }}$ day of lactation were not significant.

Percent protein. Buffalo colostrum had a significantly higher percentage of protein than milk. Colostrum is rich in antibodies (immunoglobulins) and therefore has a high percent protein. Immunoglobulins are proteins that provide passive immunity to calves. In this study, protein content in colostrum is about 3.4 times higher than in milk. A similar percent protein was reported by Arain et al. (2008) for buffalo colostrum which can be as high as $18.75 \%$ (0-4 $\mathrm{h}$ after calving) and decreases to $12.01 \%$ (4-12 $\mathrm{h}$ after calving), and further reduced to $8.75 \%(12-24 \mathrm{~h}$ after calving). On the other hand, the protein content of milk in this study (3.61\% to $4.20 \%)$ is similar to the average protein percentage $(4.0 \%)$ and range $(2.7 \%$ to $4.5 \%)$ reported by Medhammar et al. (2011) in their comprehensive review of the nutrient composition of milk from more than 16 buffalo breeds.

Percent lactose. Lactose (milk sugar) was higher in milk $(4.58 \%$ to $4.84 \%)$ than in colostrum $(2.12 \%$ to $2.40 \%)$. The lactose content in buffalo colostrum reported by Arain et al. (2008) ranges from $2.70 \%$ (0-4 h after calving) to $3.42 \%$ (12-24 h after calving), while the average lactose content in buffalo milk reported by Medhammar et al. (2011) was $4.4 \%$, ranging from $3.2 \%$ to $4.9 \%$.
Freezing point. The freezing point of buffalo colostrum was higher than that in milk. This may have been caused by the combined effect of breed and the differences in the content of lactose, and mineral composition (chloride salts, calcium, potassium, and magnesium), which have been shown to contribute to freezing point depression in milk (Jennes \& Patton, 1959 as cited by Henno et al., 2008). Large differences in protein content may also be related to the higher freezing point since variation in the mineral composition of milk can be influenced by the protein content (Henno et al., 2008). However, this study found no significant differences $(\mathrm{p}>0.05)$ in the freezing point of milk obtained on the $30^{\text {th }}, 60^{\text {th }}$, and $90^{\text {th }}$ day of lactation. In dairy cattle, Henno et al. (2008) reported that the freezing point of cow's milk was affected by the stage of lactation. The cow's milk freezing point was at its highest level during the second and third months of lactation when milk protein was at its lowest level.

The freezing point of buffalo milk in this study, ranging from $-0.517^{\circ} \mathrm{C}$ to $-0.480^{\circ} \mathrm{C}$ was higher than that reported by Khedkar et al. (2016) in India (i.e., $-0.590^{\circ} \mathrm{C}$ to $-0.518^{\circ} \mathrm{C}$ ) and Pesce et al. (2016) for the Mediterranean breed in Italy (i.e., -0.527 to $-0.545^{\circ} \mathrm{C}$ ). Incidentally, Khedkar et al. (2016) showed that the freezing point of buffalo milk is related to its soluble constituents and is affected by season $\left(-0.528^{\circ} \mathrm{C}\right.$ and $-0.531^{\circ} \mathrm{C}$ in warm and cold weathers, respectively), farm size $\left(-0.532^{\circ} \mathrm{C}\right.$ and $-0.519^{\circ} \mathrm{C}$ in small and large farms, respectively), and between organic and conventional farming methods $\left(-0.526^{\circ} \mathrm{C}\right.$ and $-0.537^{\circ} \mathrm{C}$, respectively). Pesce et al. (2016) added that the freezing point is usually lower with the presence of milk solids and the difference in solute concentrations, especially \% lactose.

\section{Comparisons Between Murrah and Its Crosses with the Carabao}

Colostrum. Colostrum from purebred Murrah buffaloes had significantly $(\mathrm{p}<0.05)$ higher protein but lower fat, fat yield, and colostrum yield than "Murrah x Carabao" crosses (Table 8). Percent moisture, \% lactose, \% SNF, $\%$ total solids, protein yield, lactose yield, and freezing

Table 7. Composition, yield, and freezing point in buffalo colostrum and milk collected on different days of lactation

\begin{tabular}{|c|c|c|c|c|}
\hline \multirow{2}{*}{ Variables } & \multirow{2}{*}{ Colostrum } & \multicolumn{3}{|c|}{ Buffalo milk collected on the } \\
\hline & & $30^{\text {th }}$ day of lactation & $60^{\text {th }}$ day of lactation & $90^{\text {th }}$ day of lactation \\
\hline \% Moisture & $78.04 \pm 0.62^{b}$ & $85.97 \pm 0.59^{a}$ & $85.68 \pm 0.59^{a}$ & $84.38 \pm 0.63^{a}$ \\
\hline$\%$ Fat & $4.34 \pm 0.41$ & $4.69 \pm 0.39$ & $5.11 \pm 0.40$ & $5.49 \pm 0.42$ \\
\hline$\%$ Protein & $12.96 \pm 0.40^{\mathrm{a}}$ & $3.61 \pm 0.38^{b}$ & $3.65 \pm 0.38^{\mathrm{b}}$ & $4.20 \pm 0.40^{\mathrm{b}}$ \\
\hline$\%$ Lactose & $2.26 \pm 0.14^{\mathrm{b}}$ & $4.62 \pm 0.13^{a}$ & $4.58 \pm 0.13^{a}$ & $4.84 \pm 0.14^{a}$ \\
\hline$\%$ Solids non-fat & $16.15 \pm 0.42^{\mathrm{a}}$ & $9.24 \pm 0.40^{\mathrm{b}}$ & $9.13 \pm 0.40^{\mathrm{b}}$ & $10.01 \pm 0.43^{\mathrm{b}}$ \\
\hline$\%$ Total solids & $21.96 \pm 0.62^{a}$ & $14.03 \pm 0.59^{b}$ & $14.32 \pm 0.59^{b}$ & $15.62 \pm 0.63^{b}$ \\
\hline Fat yield, kg & $0.27 \pm 0.02$ & $0.29 \pm 0.02$ & $0.32 \pm 0.02$ & $0.34 \pm 0.03$ \\
\hline Protein yield, kg & $0.76 \pm 0.03^{a}$ & $0.20 \pm 0.03^{b}$ & $0.21 \pm 0.03^{b}$ & $0.26 \pm 0.03^{b}$ \\
\hline Lactose yield, kg & $0.16 \pm 0.01^{b}$ & $0.29 \pm 0.01^{\mathrm{a}}$ & $0.29 \pm 0.01^{a}$ & $0.30 \pm 0.01^{a}$ \\
\hline Colostrum yield, kg & $4.95 \pm 0.34^{\mathrm{b}}$ & $6.82 \pm 0.34^{\mathrm{a}}$ & $6.64 \pm 0.34^{\mathrm{a}}$ & $6.69 \pm 0.36^{\mathrm{a}}$ \\
\hline Freezing point, ${ }^{\circ} \mathrm{C}$ & $-0.440 \pm 0.017^{a}$ & $-0.487 \pm 0.016^{\mathrm{b}}$ & $-0.480 \pm 0.016^{b}$ & $-0.517 \pm 0.017^{b}$ \\
\hline
\end{tabular}

Note: Means in the same row with different superscripts differ significantly $(\mathrm{p}<0.05)$. 
point were not significantly different $(p>0.05)$ between purebred Murrah and "Murrah x Carabao" crosses.

The colostrum parameters were generally not significantly different between the F1 " $50 \%$ Murrah - 50\% Carabao" and F2 "75\% Murrah - 25\% Carabao" crosses ( $p>0.05)$, except for colostrum yield (Table 9). The F2 crossbred buffaloes had significantly higher $(p<0.05)$ colostrum yield $(8.53 \mathrm{~kg}$ vs. $3.72 \mathrm{~kg}$ ) than F1 crossbred buffaloes.

Milk collected on different days of lactation. The composition and freezing point of milk collected on the $30^{\text {th }}, 60^{\text {th }}$, and $90^{\text {th }}$ day of lactation were generally similar for Murrah and "Murrah x Carabao" crosses (Table $8)$. This suggests that the proportion and yield of milk components and freezing point are determined by additive genes and may be improved through selection. The "Murrah x Carabao" crosses had significantly $(p<0.05)$ higher test-day milk yield (7.27 kg vs. $6.15 \mathrm{~kg})$ than purebred Murrah. Assuming low milk productivity of carabaos (not studied in this investigation), this implies that test-day milk yield is probably determined by non-additive genes and can be improved by crossbreeding. This suggests that the carabao upgrading (crossbreeding) program can be a good strategy to accelerate the herd buildup of dairy buffaloes in the country. This may not only increase milk productivity but also improve colostrum/ milk composition parameters similar with those of the Murrah breed.

The fat content, protein content, and lactose content of milk from the Murrah breed in this study were generally lower than published reports for Murrah in India (Yadav et al., 2013; Sarkar et al., 2016) and Murrah in China (Ren et al., 2015; Zhou et al., 2018). Higher fat, protein, and lactose content of milk were also reported for other buffalo breeds such as the Nili-Ravi breed in China (Sun et al., 2014; Ren et al., 2015; Zhou et al., 2018), the Mediterranean breed in Italy (Pesce et al., 2016), and the Anatolian breed in Turkey (Cinar et al., 2019).

The milk from F1 crossbred buffaloes had significantly $(\mathrm{p}<0.05)$ higher \% lactose and \% SNF, but a lower freezing point than that in F2 crossbred buffaloes (Table 10). Percent moisture, $\%$ fat, $\%$ protein, $\%$ total solids, fat yield, protein yield, lactose yield, and test-day milk yield were not significantly different $(p>0.05)$ between the F1 and F2 crossbred buffaloes.

Table 8. Composition, yield, and freezing point of buffalo colostrum and milk from purebred Murrah and "Murrah x Carabao" crosses

\begin{tabular}{|c|c|c|c|c|}
\hline \multirow[b]{2}{*}{ Variables } & \multicolumn{2}{|c|}{ Buffalo colostrum } & \multicolumn{2}{|c|}{ Buffalo milk } \\
\hline & Purebred Murrah & $\begin{array}{c}\text { “Murrah x Carabao" } \\
\text { crosses }\end{array}$ & Purebred Murrah & $\begin{array}{c}\text { "Murrah x Carabao" } \\
\text { crosses }\end{array}$ \\
\hline \% Moisture & $77.97 \pm 1.16$ & $78.61 \pm 1.24$ & $85.40 \pm 0.39$ & $85.13 \pm 0.41$ \\
\hline$\%$ Fat & $3.74 \pm 0.56^{b}$ & $5.20 \pm 0.60^{\mathrm{a}}$ & $4.97 \pm 0.32^{a}$ & $5.13 \pm 0.33^{a}$ \\
\hline$\%$ Protein & $13.54 \pm 1.01$ & $11.70 \pm 1.08$ & $3.92 \pm 0.13$ & $3.96 \pm 0.14$ \\
\hline$\%$ Lactose & $2.21 \pm 0.15$ & $2.38 \pm 0.16$ & $4.68 \pm 0.12$ & $4.65 \pm 0.12$ \\
\hline$\%$ Solids non-fat & $16.68 \pm 0.94$ & $14.97 \pm 1.01$ & $9.52 \pm 0.20$ & $9.60 \pm 0.22$ \\
\hline$\%$ Total solids & $22.03 \pm 1.16$ & $21.39 \pm 1.24$ & $14.60 \pm 0.39$ & $14.87 \pm 0.41$ \\
\hline Fat yield, kg & $0.18 \pm 0.03^{\mathrm{b}}$ & $0.26 \pm 0.03^{a}$ & $0.33 \pm 0.02^{\mathrm{a}}$ & $0.34 \pm 0.02^{\mathrm{a}}$ \\
\hline Protein yield, kg & $0.71 \pm 0.06^{\mathrm{a}}$ & $0.56 \pm 0.06^{b}$ & $0.27 \pm 0.01^{\mathrm{a}}$ & $0.27 \pm 0.01^{\mathrm{a}}$ \\
\hline Lactose yield, kg & $0.11 \pm 0.01$ & $0.11 \pm 0.01$ & $0.31 \pm 0.01$ & $0.31 \pm 0.01$ \\
\hline Test-day milk yield, kg & $3.79 \pm 0.50^{\mathrm{b}}$ & $6.13 \pm 0.53^{a}$ & $6.15 \pm 0.25^{b}$ & $7.27 \pm 0.26^{\mathrm{a}}$ \\
\hline Freezing point, ${ }^{\circ} \mathrm{C}$ & $-0.454 \pm 0.018$ & $-0.422 \pm 0.019$ & $-0.499 \pm 0.013$ & $-0.490 \pm 0.014$ \\
\hline
\end{tabular}

Note: Means in the same row (for the same milk type) with different superscripts differ significantly $(\mathrm{p}<0.05)$.

Table 9. Composition, yield, and freezing point of buffalo colostrum from different "Murrah x Carabao" crosses

\begin{tabular}{|c|c|c|c|c|}
\hline Colostrum parameters & $\begin{array}{c}\text { F1 50\% Murrah - 50\% } \\
\text { Carabao }\end{array}$ & $\begin{array}{c}\text { F2 75\% Murrah - 25\% } \\
\text { Carabao }\end{array}$ & $\begin{array}{c}\text { F3 87.5\% Murrah - } \\
\text { 12.5\% Carabao }\end{array}$ & $\begin{array}{c}\text { F4 93.75\% Murrah - } \\
\text { 6.25\% Carabao }\end{array}$ \\
\hline$\%$ Moisture & $75.68 \pm 2.88^{c}$ & $75.40 \pm 3.50^{\mathrm{bc}}$ & $79.38 \pm 1.67^{\mathrm{ab}}$ & $83.82 \pm 3.29^{a}$ \\
\hline$\%$ Fat & $4.70 \pm 1.49$ & $5.97 \pm 1.81$ & $5.53 \pm 0.86$ & $4.18 \pm 1.70$ \\
\hline$\%$ Protein & $15.13 \pm 2.48^{a}$ & $14.04 \pm 3.02^{\mathrm{ab}}$ & $10.59 \pm 1.44^{b}$ & $7.64 \pm 2.83^{b}$ \\
\hline$\%$ Lactose & $1.77 \pm 0.37$ & $2.00 \pm 0.45$ & $2.56 \pm 0.21$ & $3.14 \pm 0.42$ \\
\hline$\%$ Solids non-fat & $17.70 \pm 2.38^{a}$ & $16.89 \pm 2.89^{\mathrm{ab}}$ & $14.12 \pm 1.38^{\mathrm{ab}}$ & $11.55 \pm 2.72^{\mathrm{b}}$ \\
\hline$\%$ Total solids & $24.32 \pm 2.88^{a}$ & $24.60 \pm 3.50^{\mathrm{ab}}$ & $20.62 \pm 1.67^{b c}$ & $16.17 \pm 3.29 c$ \\
\hline Fat yield, kg & $0.25 \pm 0.08$ & $0.32 \pm 0.09$ & $0.27 \pm 0.04$ & $0.19 \pm 0.09$ \\
\hline Protein yield, kg & $0.76 \pm 0.15^{\mathrm{a}}$ & $0.73 \pm 0.18^{\mathrm{ab}}$ & $0.49 \pm 0.08^{b}$ & $0.33 \pm 0.17^{b}$ \\
\hline Lactose yield, kg & $0.09 \pm 0.02^{\mathrm{b}}$ & $0.08 \pm 0.02^{\mathrm{bc}}$ & $0.12 \pm 0.01^{b}$ & $0.16 \pm 0.02^{a}$ \\
\hline Colostrum yield, kg & $3.72 \pm 1.28^{c}$ & $8.54 \pm 1.42^{\mathrm{a}}$ & $6.35 \pm 0.70^{\mathrm{b}}$ & $6.68 \pm 1.44^{\mathrm{ab}}$ \\
\hline Freezing point, ${ }^{\circ} \mathrm{C}$ & $-0.421 \pm 0.048$ & $-0.432 \pm 0.057$ & $-0.422 \pm 0.030$ & $-0.423 \pm 0.053$ \\
\hline
\end{tabular}

Note: Means in the same row with different superscripts differ significantly $(\mathrm{p}<0.05)$. 
Table 10. Composition, yield, and freezing point of buffalo milk from different "Murrah x Carabao" crosses

\begin{tabular}{|c|c|c|c|c|}
\hline Milk parameters & $\begin{array}{c}\text { F1 50\% Murrah - 50\% } \\
\text { Carabao }\end{array}$ & $\begin{array}{c}\text { F2 75\% Murrah }-25 \% \\
\text { Carabao }\end{array}$ & $\begin{array}{c}\text { F3 87.5\% Murrah - } \\
\text { 12.5\% Carabao }\end{array}$ & $\begin{array}{c}\text { F4 93.75\% Murrah - } \\
\text { 6.25\% Carabao }\end{array}$ \\
\hline \% Moisture & $84.94 \pm 1.04$ & $85.25 \pm 1.12$ & $85.68 \pm 0.58$ & $83.17 \pm 1.13$ \\
\hline$\%$ Fat & $4.59 \pm 0.84^{\mathrm{b}}$ & $6.15 \pm 0.91^{\mathrm{ab}}$ & $4.72 \pm 0.47^{b}$ & $6.48 \pm 0.91^{\mathrm{a}}$ \\
\hline$\%$ Protein & $4.30 \pm 0.35$ & $3.56 \pm 0.38$ & $3.86 \pm 0.20$ & $4.22 \pm 0.38$ \\
\hline$\%$ Lactose & $4.87 \pm 0.30^{\mathrm{a}}$ & $4.16 \pm 0.32^{\mathrm{b}}$ & $4.59 \pm 0.17^{\mathrm{ab}}$ & $5.01 \pm 0.32^{\mathrm{a}}$ \\
\hline$\%$ Solids non-fat & $10.19 \pm 0.54^{a}$ & $8.59 \pm 0.58^{b}$ & $9.46 \pm 0.30^{\mathrm{a}}$ & $10.28 \pm 0.58^{a}$ \\
\hline$\%$ Total solids & $15.06 \pm 1.04^{\mathrm{ab}}$ & $14.75 \pm 1.12^{\mathrm{ab}}$ & $14.32 \pm 0.58^{b}$ & $16.83 \pm 1.13^{\mathrm{a}}$ \\
\hline Fat yield, kg & $033 \pm 0.06$ & $0.39 \pm 0.06$ & $0.31 \pm 0.03$ & $0.41 \pm 0.06$ \\
\hline Protein yield, kg & $0.29 \pm 0.04$ & $0.23 \pm 0.04$ & $0.27 \pm 0.02$ & $0.28 \pm 0.04$ \\
\hline Lactose yield, kg & $0.32 \pm 0.02^{\mathrm{ab}}$ & $0.27 \pm 0.02^{\mathrm{b}}$ & $0.31 \pm 0.01^{\mathrm{ab}}$ & $0.34 \pm 0.02^{\mathrm{a}}$ \\
\hline Test-day milk yield, kg & $7.14 \pm 0.69$ & $6.53 \pm 0.75$ & $7.65 \pm 0.38$ & $6.61 \pm 0.75$ \\
\hline Freezing point, ${ }^{\circ} \mathrm{C}$ & $-0.556 \pm 0.036^{c}$ & $-0.412 \pm 0.037^{a}$ & $-0.489 \pm 0.019^{b}$ & $-0.488 \pm 0.037^{\mathrm{b}}$ \\
\hline
\end{tabular}

Note: Means in the same row with different superscripts differ significantly $(\mathrm{p}<0.05)$.

Milk from F1 "50\% Murrah - 50\% Carabao" and F2 "75\% Murrah - 25\% Carabao" crossbreeds had lower fat, protein, and lactose contents than milk from F1 and F2 "Murrah x local swamp buffalo (Guangxi/Yunnan)" crosses in China (Sun et al., 2014; Ren et al., 2015; Han et al., 2017). Incidentally, the milk from the Chinese F1 and F2 crossbreeds had better nutritional value in terms of fat, protein, and lactose contents than those of the Murrah breed. The fat, protein, and lactose content of milk were, however, not significantly different between crossbred F1 and F2 buffaloes.

The discrepancy between our results and those of other studies in other countries may be due to the different maintenance and feeding conditions, as well as in experimental methods. Nevertheless, the results of this study add to widen the biodiversity knowledge base, which is important to the conservation and sustainable use of milk from purebred Murrah and "Murrah x Carabao" crosses in the Philippines.

\section{Implications}

This study provided evidence that the Murrah $\mathrm{x}$ Carabao crossbreeding program can lead to improvements in milk composition parameters similar to those of the Murrah breed. Since test-day milk yield in buffaloes was positively correlated to yield of fat, protein, and lactose, the local herds having the Murrah breed, "Murrah x Carabao" crosses, or a mix of both, that already have above average milk components may focus on increasing milk yield. However, test-day milk yield was positively correlated to \% protein but not related to $\%$ fat and $\%$ lactose. Herds that are below the breed average for protein may thus seem to benefit from including protein yields in the sire selection criteria for the Murrah herd. While changes in the herd's milk protein concentration may be achieved through genetic selection, the basic production and husbandry practices to increase milk yield should be improved further. Meanwhile, the detrimental effects of a high average monthly temperature on test-day milk yield and high average monthly relative humidity on protein yield can both be mitigated to achieve higher than average levels of proteins in buffalo milk.
Furthermore, by integrating the characteristics of milk from Murrah and "Murrah x Carabao" crosses with existing "Food Composition Tables" and "Food Exchange Lists", consumers will benefit from a better understanding of buffalo milk and determining the adequacy of nutrients when drinking buffalo milk. Alternatively, buffalo colostrum, especially rich in protein compounds, may offer extra benefits as a functional food for adult humans. In this case, higher protein content in colostrum may be obtained from purebred Murrah buffaloes, albeit lower colostrum yield compared to "Murrah x Carabao" crosses.

\section{CONCLUSION}

This study showed significant breed differences (Murrah vs. "Murrah x Carabao" crosses) for colostrum yield (including its protein yield and fat yield) and for test-day milk yield. The composition and freezing point of colostrum and milk were, however, similar for Murrah and "Murrah x Carabao" crosses. While new information on breed (genetic) similarities and differences are important in managing the local dairy buffalo farms, this study also showed that non-genetic factors such as age at calving, number of lactations (or parity), and high average monthly temperature may also cause changes in the composition and yield of buffalo colostrum and milk.

\section{CONFLICT OF INTEREST}

We certify that there is no conflict of interest with any financial, personal, or other relationships with other people or organizations related to the material discussed in the manuscript.

\section{ACKNOWLEDGEMENT}

This research was supported by grants from the Philippine Agriculture and Fisheries Biotechnology Program under the Department of Agriculture Biotechnology Program (DA-BIOTECH) - R1807. The authors acknowledge Dr. Rommel V. Herrera and the staff of the Philippine Carabao Center at UPLB for sup- 
plying their animals, feeding, care of the animals, and for their assistance in the sampling of milk. The authors would also like to thank Carl E. Casal and Mark C. Agsunod for their valuable assistance in handling and analysis of milk samples.

\section{REFERENCES}

Arain, H. H., M. Khaskheli, M. A. Arain, A. H. Soomro, \& A. H. Nizamani. 2008. Heat stability and quality characteristics of postpartum buffalo milk. Pak. J. Nutr. 7:303-307. https:// doi.org/10.3923/pjn.2008.303.307

Cinar, M. U., T. Ozsoy, S. B. Beyzi, M. Kaliber, \& Y. Konca. 2019. Milk fatty acid composition of Anatolian water buffalo (Bubalus bubalis) from different provinces. Buffalo Bull. 38:107-118. https://kuojs.lib.ku.ac.th/index.php/BufBu/ article/view/2450

Han, B. Z., Y. Meng, M. Li, Y. X. Yang, F. Z. Ren, Q. K. Zeng, \& M. J. R. Nout. 2017. A survey on the microbiological and chemical composition of buffalo milk in China. Food Control 18:742-746. https://doi.org/10.1016/j. foodcont.2006.03.011

Henno, M., M. Ots, I. Joudu, T. Kaart, \& O. Kart. 2008. Factors affecting the freezing point stability of milk from individual cows. Int. Dairy J. 18:210-215. https://doi.org/10.1016/j. idairyj.2007.08.006

Khedkar, C. D., S. D. Kalyankar, \& S. S. Deosarkar. 2016. Buffalo Milk. In: B. Caballero, P. Finglas, \& F. Toldra (Eds). The Encyclopedia of Food and Health. Vol. 1. Academic Press, Oxford. p. 522-528. https://doi.org/10.1016/ B978-0-12-384947-2.00093-3

Medhammar, E., R. Wijesinha-Bettoni, B. Stadlmayr, E. Nilsson, U. R. Charrondiere, \& B. Burlingame. 2011. Composition of milk from minor dairy animals and buffalo breeds: A biodiversity perspective. J. Sci. Food Agric. 92:445-474. https://doi.org/10.1002/jsfa.4690
Pesce, A., C. Salzano, A. De Felice, F. Garofalo, S. Liguori, A. De Santo, P. Palermo, \& A. Guarin. 2016. Monitoring the freezing point of buffalo milk. Ital. J. Food Saf. 5:5691. https://doi.org/10.4081/ijfs.2016.5691

PSA (Philippine Statistics Authority). 2016. Dairy Industry Performance Report - May 20, 2016. Philippine Statistics Authority (PSA). Diliman, Quezon City. https://psa. gov.ph/sites/default/files/DAIRY\%20Industry\%20 Performance\%20Report \%20-\%20Jan\%20-\%20Dec\%20 2015_1.pdf. [1 August 2020].

Ren, D. X., C. X. Zou, L. Bo, Y. L. Chen, X. W. Liang, \& J. X. 2015. A comparison of milk protein, amino acid and fatty acid profiles of river buffalo and their F1 and F2 hybrids with swamp buffalo in China. Pak. J. Zool. 47:1459-1465.

Sarkar, U., A.K. Gupta, V. Sarkar, T. K. Mohanty, V. S. Raina, \& S. Prasad. 2016. Factors affecting test day milk yield and milk composition in dairy animals. J. Dairy. Foods Home Sci. 25:129-132. https://www.researchgate.net/ publication/265334702

SAS (Statistical Analysis System). 2009. SAS/STAT ® 9.2 User's Guide. $2^{\text {nd }}$ Ed. SAS Institute, Inc. Cary, NC USA.

Sun, Q., J. P. Lv, L. Liu, S. W. Zhang, X. Liang, \& J. Lu. 2014. Comparison of milk samples collected from some buffalo breeds and crossbreeds in China. Dairy Sci. Technol. 94:387-395. https://doi.org/10.1007/s13594-013-0159-9

Yadav, S. P., P. Sikka, D. Kumar, S. Sarkar, A. K. Pandey, P. S. Yadav, \& R. K. Sethi. 2013. Variation in milk constituents during different parity and seasons in Murrah buffaloes. Indian J. Anim. Sci. 83:747-751.

Zhou, L., Q. Tang, M. W. Iqbal, Z. Xia, F. Huang, L. Li, M. Liang, B. Lin, G. Qin, \& C. Zou. 2018. A comparison of milk protein, fat, lactose, total solids and amino acid profiles of three different buffalo breeds in Guangxi, China. Ital. J. Anim. Sci. 17:873-878. https://doi.org/10.1080/18280 51X.2018.1443288 